\title{
Responses of early-successional songbirds to a two-stage shelterwood harvest for oak forest regeneration
}

Eric L. Margenau ${ }^{1,2^{*}}$, Yong Wang ${ }^{1}$, Callie J. Schweitzer ${ }^{3}$ and Brandie K. Stringer ${ }^{1}$

\begin{abstract}
Background: The early stage of forest succession following disturbance is characterized by a shift in songbird composition as well as increased avian richness due to increased herbaceous growth in the forest understory. However, regeneration of woody species eventually outcompetes the herbaceous understory, subsequently shifting vegetation communities and decreasing availability of vital foraging and nesting cover for disturbance-dependent birds, ultimately resulting in their displacement. These early stages following forest disturbance, which are declining throughout the eastern United States, are ephemeral in nature and birds depend on such disturbances for nesting and other purposes throughout their lives.
\end{abstract}

Methods: We investigated the use of a two-stage shelterwood method to manage long-term persistence of seven early successional songbirds over a 13-year period in an upland hardwood forest within the southern end of the midCumberland Plateau in the eastern United States.

Results: Canopy and midstory gaps created after initial harvest were quickly exploited by tree growth and canopy cover returned to these areas, accelerating the displacement of early-successional species. Woody stem densities increased substantially following stage two harvest as advanced tree regeneration combined with the re-opening of the overstory layer increased resource competition for early-successional plants in the understory. Carolina Wren (Thryothorus ludovicianus), Eastern Towhee (Pipilo erythrophthalmus), Indigo Bunting (Passerina cyanea), and Yellowbreasted Chat (Icteria virens) were characterized by immediate increases following initial harvest in 2001; while the American Goldfinch (Spinus tristis), Prairie Warbler (Setophaga discolor), and White-eyed Vireo (Vireo griseus) did not show an immediate response. Stage two harvest in 2011 rejuvenated vegetation which benefitted focal species, with six of seven species showing increases in densities between 2010 and 2012.

Conclusion: The two-stage shelterwood method created conditions advantageous to early-successional birds by helping to re-establish understory vegetation through periodic disturbance to the canopy layer. This method provides evidence that early-successional species can be managed long-term (> 15 years) while using relatively small spatial disturbance through the two-stage shelterwood method.

Keywords: Early-successional forests, Mid-Cumberland Plateau, Silviculture, Shelterwood, Songbird community

\footnotetext{
*Correspondence: margenaueric@gmail.com

${ }^{1}$ Department of Biological and Environmental Sciences, Alabama A\&M

University, Normal, AL 35762, USA

Full list of author information is available at the end of the article
} 


\section{Background}

Studies of songbird population fluctuations, as a function of timber management, are common (see Sallabanks et al. 2000; Brawn et al. 2001; Vanderwel et al. 2007) due to concerns of declining songbird populations as a result of decreasing total areas of natural habitats (e.g., forests, shrublands, savannas) in the eastern United States (US) (Hunter et al. 2001; Drummond and Loveland 2010; Sauer and Link 2011). Forest management practices can help alleviate habitat-related pressures felt by songbird species through the creation of heterogeneous vegetation structures (Thompson III et al. 1993; Perry and Thill 2013; Rankin and Perlut 2015). Forest management practices and songbird conservation may differ in their objectives (timber production versus maintaining rich ecological communities, respectively), but they both benefit by periodic forest disturbance. Land (or forest) managers are often interested in returning harvested stands to their former tree composition using various silvicultural practices. Through the implementation of these different silviculture techniques, tree harvest has also shown it can benefit songbird species characterized as early-successional obligates (Klaus et al. 2005; McDermott and Wood 2009). An important and often overlooked stage of forest succession occurs immediately following forest disturbances (i.e., tree harvest; Askins 2001; Swanson et al. 2011), where woody and non-woody plants in the understory are prominent vegetation features (Decocq et al. 2004). Until recently, the early-successional habitat (or young forest, shrubland; Litvaitis 2003) was thought to have low ecological importance (Swanson et al. 2011) and largely ignored (Askins 2001). However, many species of songbird rely on this stage of forest succession either for a portion of or for their entire life (Trani et al. 2001; Swanson et al. 2011; Oswalt et al. 2012). The early-successional habitat is critical for avifauna by provisioning essential functions during the nesting and post-nesting period including nesting cover (Confer and Pascoe 2003; Smetzer et al. 2014), cover from predators (Vitz and Rodewald 2006; Chandler et al. 2012), and foraging resources (Vega Rivera et al. 1998; McDermott and Wood 2010). Unfortunately, the distribution and total amount of early-successional habitat have recently declined throughout eastern US due to historical reasons (restrictions on logging, farm abandonment, or suppression of fire; Lorimer 2001; Trani et al. 2001), which are currently being compounded by land conversion (e.g., urban sprawl). Continued decreases in total area will likely have negative implications for songbird species associated with early-successional habitats (Dettmers 2003; King and Schlossberg 2014).

In recent decades, active management relating to ecosystem functions has facilitated greater understanding of forest use for timber production while sustaining ecosystem viability (Franklin et al. 1986; Franklin 1989; Hansen et al. 1991). The staged shelterwood method used to regenerate oak-dominated forests in the eastern US follows this framework as overstory trees are removed in one or two stages, promoting advanced regeneration of oak and other species in the understory under the protection of the remaining canopy (Loftis 1990). The shelterwood method can create varied temporal and spatial stand conditions suitable to a range of avian communities (Thompson III et al. 1995; Newell and Rodewald 2012), particularly bird species relying on early-successional forest habitats (Annand and Thompson III 1997; Goodale et al. 2009). However early-successional forest conditions are often transient, constrained by plant regeneration following canopy removal (DeGraaf and Yamasaki 2003; Schlossberg and King 2009; Schlossberg et al. 2010).

There are many scientific papers that have studied the relationships between bird communities and forest management practices (Baker and Lacki 1997; Campbell et al. 2007; Augenfeld et al. 2008). Although no study has ever examined the effects of the two-stage shelterwood method on the early-successional songbird community to test whether periodic disturbances can be a useful technique for early-successional songbird management. The objectives of this study were to provide a descriptive assessment (see "Statistical analyses" section for further explanation) of the vegetation and early-successional songbird community's responses to a two-stage shelterwood harvest and to test how varying tree basalarea retention harvests for oak forest regeneration might affect the habitat and bird community dynamics.

\section{Methods}

Study area

Study sites were located in northern Jackson County, Alabama, USA on the southern end of the mid-Cumberland Plateau $\left(34^{\circ} 57^{\prime} \mathrm{N}, 86^{\circ} 08^{\prime} \mathrm{E}\right.$; Fig. 1a). To ensure proper replication, two sites within close proximity (11.7 km apart) with similar habitat characteristics were selected by the Forest Service (FS) of the US Department of Agriculture (USDA). Three block replications were implemented, one at Miller Mountain (Fig. 1b) and two at Jack Gap (Fig. 1c). Each block consisted of five stands implemented in 2001, with an additional control stand being added in 2011 (totaling 18 stands). Miller Mountain has a mean elevation of $500 \mathrm{~m}$ with a southwestern aspect and Jack Gap has elevations of 450 and $360 \mathrm{~m}$ with northern aspects; slopes at both sites range between 15 and 30\% (Schweitzer 2004). The climate of this region is characterized by long and moderately hot summers, and short and mild winters (Smalley 
a

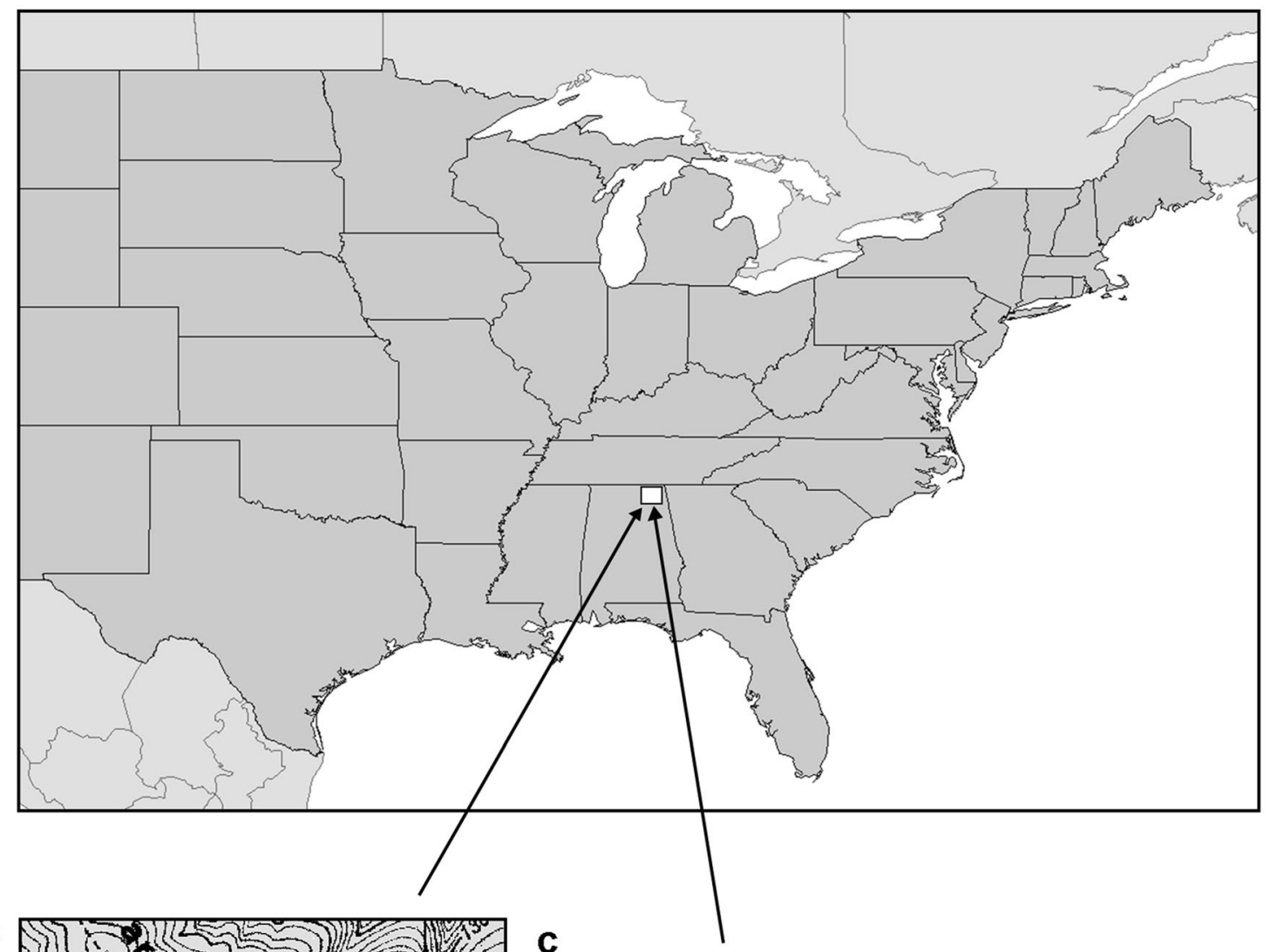

b

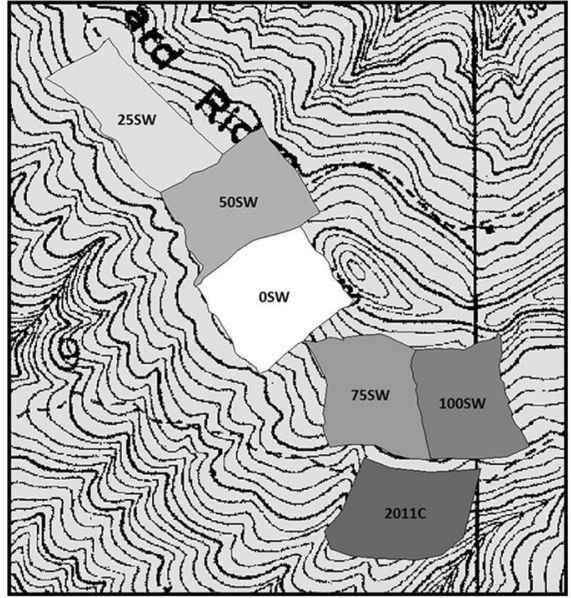

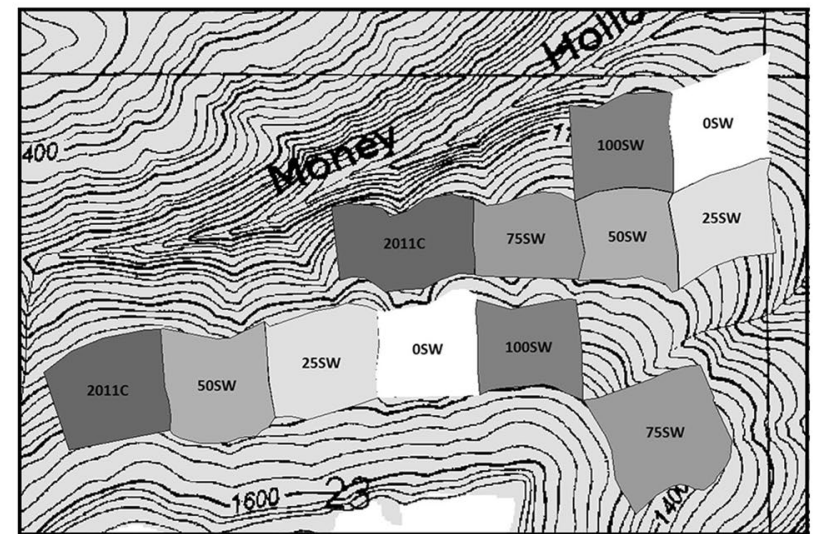

Fig. 1 Location of study sites in the eastern United States (a). Randomized block replicate layout of three blocks, each with six different treatments (0SW, 25SW, 50SW, 75SW, 100SW, and 2010C). Miller Mountain (b) has a mean elevation of $500 \mathrm{~m}$ with a southwestern aspect. Jack Gap (c) has mean elevations of $450 \mathrm{~m}$ and $360 \mathrm{~m}$ with northern aspects. Slopes at both sites range between 15 and 30\%. Stands are 4 ha in size

1982). Forest stands at the study sites were mainly composed of oaks (Quercus velutina, Q. rubra, Q. alba, Q. prinus), yellow poplar (Liriodendron tulipifera), hickories (Carya spp.) and sugar maple (Acer saccharum) (Schweitzer 2004). For clarity, 'stage one' harvest refers to the initial tree harvest or herbicide treatment in 2001 and 'stage two' harvest refers to the canopy harvest in 2010.

\section{Study design}

Within each block, five stands each received one of five basal area retention treatments (0 [clearcut], 25, 50, 75, and 100 [control] percent retention). Stands were 4 ha in 
size and roughly square in shape. During stage one, trees in the 0 (herein referred to as 'OSW'), 25 (herein referred to as ' $25 \mathrm{SW}$ '), and 50 (herein referred to as ' $50 \mathrm{SW}$ ') percent retention treatments were harvested by chain saw felling and grapple skidding. Stands with the 75 (herein referred to as '75SW') percent retention treatment had the midstory removed by stem injection using an herbicide (Arsenal ${ }^{\circledR}$, active ingredient imazapyr) (Schweitzer 2004). Stands receiving the 100 (herein referred to as '100SW') percent retention treatment were undisturbed. All fifteen stands were allowed to grow for 8 years, prior to final harvest (stage two removal) in 2010 (Schweitzer and Dey 2017). During stage two removal, remaining merchantable trees $(\geq 14 \mathrm{~cm}$ diameter at breast height $(\mathrm{DBH}))$ in the $25 \mathrm{SW}, 50 \mathrm{SW}, 75 \mathrm{SW}$ and $100 \mathrm{SW}$ were removed while the $0 \mathrm{SW}$ was left undisturbed. Three new control stands (one per block) were installed (see Schweitzer 2004 for further information). Consequently, five forest stand conditions were created in 2010: (1) 8-year old regeneration ('old clearcut', which consisted of OSW stands), (2) released regeneration type 1, with more vertical structure due to the new sprouts from midstory and overstory trees and remaining or advanced growth of understory/midstory after the initial canopy removal in 2002 (consisted of 25SW and 50SW stands), (3) released regeneration type 2 , with less vertical structure due to the killing of the midstory from herbicide during the initial treatment in 2002 which subdued resprouting (consisted of 75SW stands), (4) 'new clearcut' (the 'old control') (consisted of 100SW stands), and (5) mature or 'new control', forest stands that had not been disturbed for greater than 40 years (herein referred to as '2010C').

\section{Habitat assessment}

Five randomly generated 0.01 ha plots within each stand were used to measure habitat change over the study period. Percent overstory canopy cover was measured using a hand-held spherical densitometer at $1.4 \mathrm{~m}$ above the forest floor (Fiala et al. 2006; Korhonen et al. 2006). Woody stem data were enumerated from live trees measured, and classified into five diameter at breast height (DBH) categories $(\leq 2.5, \geq 2.6-5.0, \geq 5.1-7.5, \geq 7.6-10.0$, and $\geq 10.1 \mathrm{~cm}$ ) (Schweitzer and Dey 2011) then divided by 4 to calculate stems/ha (stands were 4 ha in size). All woody stems measuring $\geq 10.1 \mathrm{~cm} \mathrm{DBH}$ (canopy trees) were grouped into a single category since the focus of this study was on forest regeneration (small diameter trees). We averaged all collected data at the stand level and grouped those averages based on treatment type for each year collected. Stem measurements were taken during the 2001-03, 2009, 2011, and 2014 seasons and canopy measurements were taken during the 2002-06, 2009, 2011, and 2014 seasons.

\section{Bird community surveys}

The spot-mapping method (Ralph et al. 1993; Bibby et al. 2000) was used to determine territory density of selected songbirds during the peak of the breeding season (May 1-June 30) of the targeted species in 2002, 2003, 2010, 2012, 2013, and 2014. This technique was appropriate for this study because (1) stands were relatively small in size (4 ha) making accuracy feasible, (2) stands were all equal in area (which helps eliminate area-dependent variation), (3) all stands were roughly square in shape and had comparatively short total edge length (reducing the influence of edge effect on the bird community), and (4) because there were multiple surveyors, this technique reduces inter-observer bias as well as differences in experience of surveyors (McLaren and Cadman 1999). Each stand received 10 spot-mapping visits ( $\geq 3$ days between visits) through the season in each year. Surveys started around 0500-0530 (CST) and lasted approximately $5 \mathrm{~h}$ each day, with each stand being surveyed for 45-60 min. Stands were surveyed by walking two parallel transects that evenly dissected each stand. Surveyors estimated locations of all bird species on a topographic map using pre-located markers along transect routes. Each stand visit was recorded on a separate data sheet, and all sheets were overlaid to delineate territories after all surveys were completed. Stand order and entrance were rotated to account for daily and temporal variation in songbird activities. Territory of an individual was determined by $\geq 3$ detections over the 10 visits, with $\geq 2$ of those detections occurring during non-simultaneous visits. Because stands were directly adjacent to one another, species that were recorded in two separate stands had their territory divided into $1 / 2$ or $1 / 4$ territories depending on location. About 17\% (113 of 670 total species territories) were delineated and split between adjacent forest stands. Mean territory density of each species was calculated by dividing raw territory values for each stand by 4 (stands were 4 ha in size).

We selected bird species that were characterized as early-successional or disturbance-dependent (Blake and Karr 1987; Freemark and Collins 1992) with at least 10 territories 1 year during the 6-year study period. Species included in analyses were American Goldfinch (Spinus tristis), Carolina Wren (Thryothorus ludovicianus), Eastern Towhee (Pipilo erythrophthalmus), Indigo Bunting (Passerina cyanea), Prairie Warbler (Setophaga discolor), White-eyed Vireo (Vireo griseus), and Yellow-breasted Chat (Icteria virens). These songbird species were selected because they represented over $90 \%$ of territories from early-successional species group during the study, and selected species have been used in similar studies. 


\section{Statistical analyses}

This study was first implemented as a silviculture study focusing on oak-hickory regeneration with avian community sampling added at a later date. Because avian sampling was not initially a priority in study design setup, statistical analyses relating the avian community to treatment type (0SW, 25SW, 50SW, 75SW, 100SW, and 2010C) were subject to some limitations. We were interested in determining whether basal retention treatments affected focal songbird densities, whether densities of focal songbirds changed over time (2002, 2003, 2010, and 2012-2014), while also investigating the interaction between treatments and years. We estimated the density of each focal species in each treatment (via ten replicated territory mapping visits each year) to produce a single density value for each treatment. This resulted in three replicated estimates of songbird density (one for each block replicate) for the six (five in 2002, 2003, and 2010) different treatment types each year. When using statistical models to predict relationship between predictor and response variables, small replication size increases the potential of overfitting models and limits predictive powers from our results (Babyak 2004). Due to the limited statistical power and the attempt to avoid erroneous conclusions based on our statistical analyses, we present descriptive results below. We assessed patterns of vegetation variables and songbird species' densities across treatment type, year, and within treatment types through years.

\section{Results \\ Habitat \\ Canopy cover}

Following stage one harvest, canopy cover in the 75SW and 100SW treatments remained high, while all other treatments (0SW, 25SW, and 50SW) showed a decrease during 2002 and 2003 (immediately following harvest in 2001). Canopy cover in the 0SW, 25SW, and 50SW treatments increased in 2004 (3 years following harvest) (Fig. 2). By 2005 (4 years after stage one harvest), canopy cover in $0 \mathrm{SW}, 25 \mathrm{SW}$, and $50 \mathrm{SW}$ treatments reached relatively high levels (comparable to $75 \mathrm{SW}$ and $100 \mathrm{SW}$ treatments) until stage two harvest. Following stage two harvest in 2010, canopy cover declined in all treatments that received tree harvest (25SW, 50SW, 75SW, and $100 \mathrm{SW}$ ). Canopy cover in $25 \mathrm{SW}, 50 \mathrm{SW}, 75 \mathrm{SW}$, and $100 \mathrm{SW}$ treatments increased in 2014 (3 years after stage two harvest), which was similar to canopy responses following stage one harvest (in 0SW, 25SW, and 50SW treatments). Vegetation response was quicker following stage two harvest, with 1 year of reduced canopy in 2011 compared to 2 years of successive canopy decline in 2002

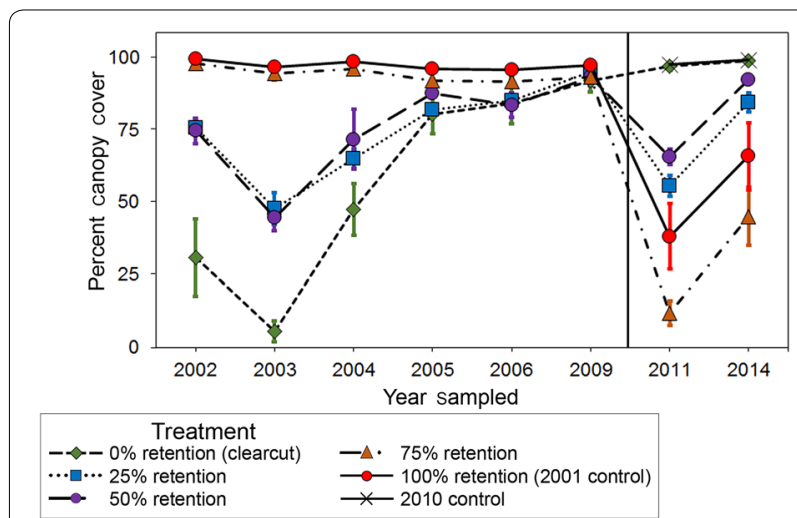

Fig. 2 Mean percent canopy cover and standard error of six different silviculture treatments during 2002-2006, 2009, 2011, and 2014. Solid black vertical line indicates when stage two harvest occurred (2010)

and 2003 (Fig. 2), possibly due to advanced regeneration already present in the midstory at the time of stage two harvest.

\section{Stem classes}

Stems/ha of $0-2.5 \mathrm{~cm}$ and $\geq 2.6-5.0 \mathrm{~cm} \mathrm{DBH}$ classes remained low during stage one, but increased prior to and following stage two harvest in treatments that received canopy removal during stage one (0SW, 25SW, and $50 \mathrm{SW})$. Stems $/$ ha of the $\geq 10.1 \mathrm{~cm} \mathrm{DBH}$ class decreased in treatments that received tree harvest in stage one (0SW, $25 \mathrm{SW}$, and $50 \mathrm{SW})$ and in stage two $(75 \mathrm{SW}$ and $100 \mathrm{SW}$ stands; Fig. 3). Stems/ha of the $\geq 5.1-7.5 \mathrm{~cm} \mathrm{DBH}$ class were greater in $100 \mathrm{SW}$ compared to other treatments during stage one due to a lack of advanced regeneration in OSW, 25SW, and 50SW stands coupled with midstory kill in $75 \mathrm{SW}$ stands following stage one harvest. Stems/ha of the $\geq 7.6-10.0 \mathrm{~cm}$ DBH class were low (compared to other stem classes) through the entire study period, with the most evident reduction in density appearing immediately following stage one harvest (Fig. 3). Due to high competition during the regeneration stage (resources directed towards stem height rather than stem diameter), there was minimal response in the $\geq 7.6-10.0 \mathrm{~cm} \mathrm{DBH}$ class which resulted in little change over time.

\section{Bird community}

The use by American Goldfinch, Prairie Warbler, and White-eyed Vireo was delayed immediately following stage one tree harvest in $0 \mathrm{SW}, 25 \mathrm{SW}$, and $50 \mathrm{SW}$ treatments. American Goldfinch densities increased in treatments receiving any tree harvest during stage two (25SW, 50SW, 75SW, and 100SW), while densities in treatments receiving no harvest (OSW and 2010C) remained low. Prairie Warbler densities immediately increased in treatments that had tree harvest during stage two (25SW, 

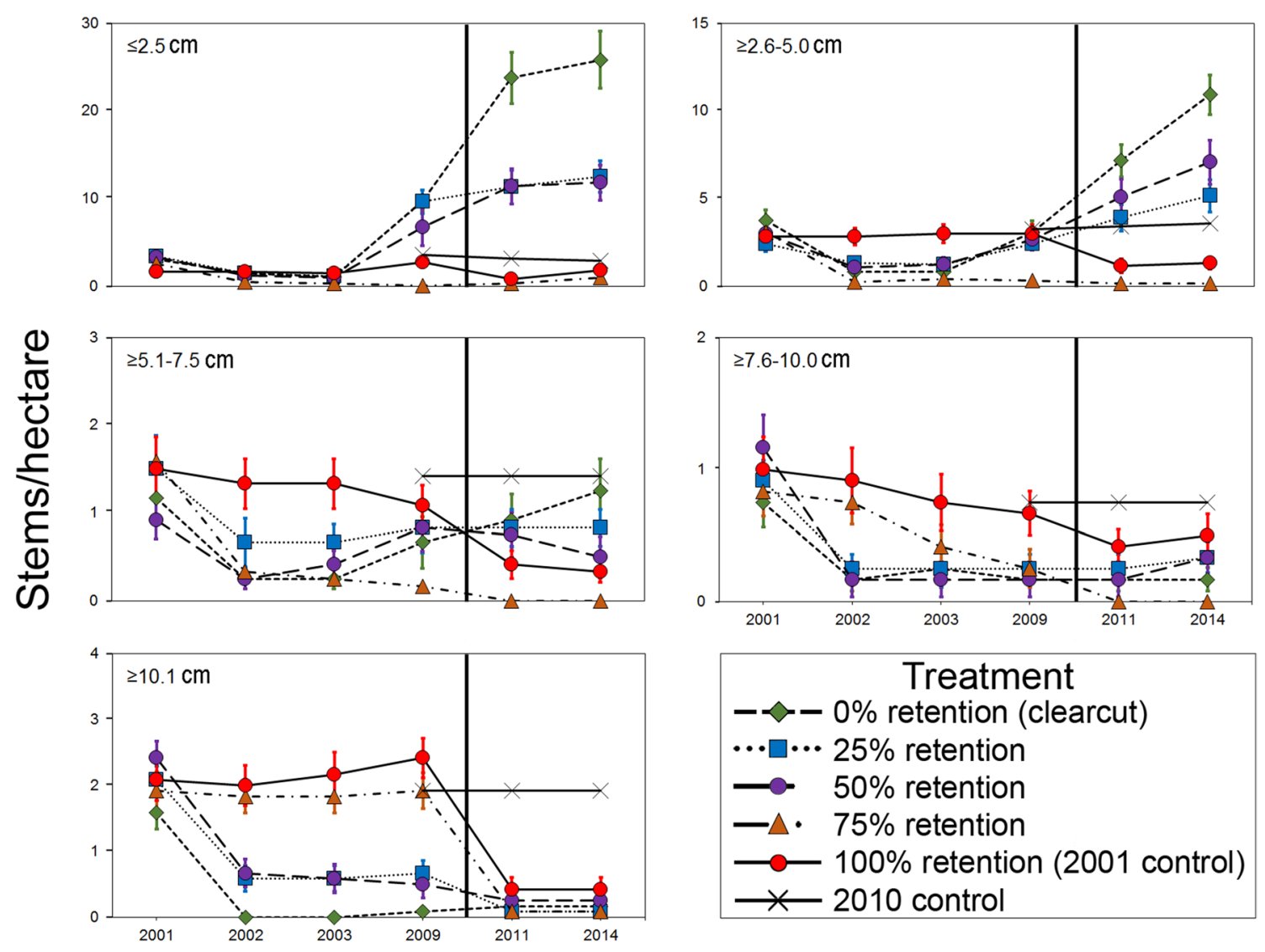

\section{Year sampled}

Fig. 3 Woody stems/hectare for five different stem classes in six different silviculture treatments (0\% retention, 25\% retention, 50\% retention, $75 \%$ retention, 100\% retention, 2010 control) over 13 years in an upland hardwood forest in northeastern Alabama. Solid black vertical line indicates when stage two harvest occurred (2010)

50SW, 75SW, and 100SW) and densities gradually increased in these treatments following stage two harvest (Fig. 4). Similar to the American Goldfinch, Prairie Warblers were not detected in treatments that were left undisturbed during stage two harvest (OSW and 2010C). White-eyed Vireo densities increased greatly between 2003 and 2010 (Fig. 4) in treatments receiving moderate to heavy tree harvest (0SW, 25SW, and 50SW) but remained low in minimally disturbed treatments $(75 \mathrm{SW}$ and $100 \mathrm{SW})$. Following stage two harvest, White-eyed Vireo densities increased in treatments that had drastic canopy change (75SW and 100SW, Fig. 2) and remained generally consistent in $25 \mathrm{SW}$ and $50 \mathrm{SW}$ stands while decreasing in OSW stands.

Indigo Bunting and Yellow-breasted Chat densities increased immediately following stage one in treatments receiving tree harvest (0SW, 25SW, and 50SW). Between 2003 and 2010, Indigo Bunting densities declined but still remained at high levels (relative to other species' densities). Following stage two harvest, Indigo Bunting density increased in all but one treatment (OSW), and remained generally consistent following stage two harvest for all but OSW, in which densities decreased. Yellow-breasted Chats shared a similar pattern as Indigo Buntings, with increased densities in all but OSW stands following stage two harvest. Yellow-breasted Chat densities between 2010 and 2012 (immediately pre- and poststage two harvest) increased noticeably in the $75 \mathrm{SW}$ and 100SW stands, while densities in 25SW and 50SW stands remained consistent, similar to the Indigo Bunting (Fig. 4).

Carolina Wrens lacked a consistent pattern during stage one of the study but densities were generally higher in treatments with moderate to heavy tree harvest (0SW, $25 \mathrm{SW}$, and 50SW). Following stage two harvest, densities were higher in treatments that received tree harvest (25SW, 50SW, 75SW, and 100SW) and remained stable following stage two tree harvest. This pattern was true 

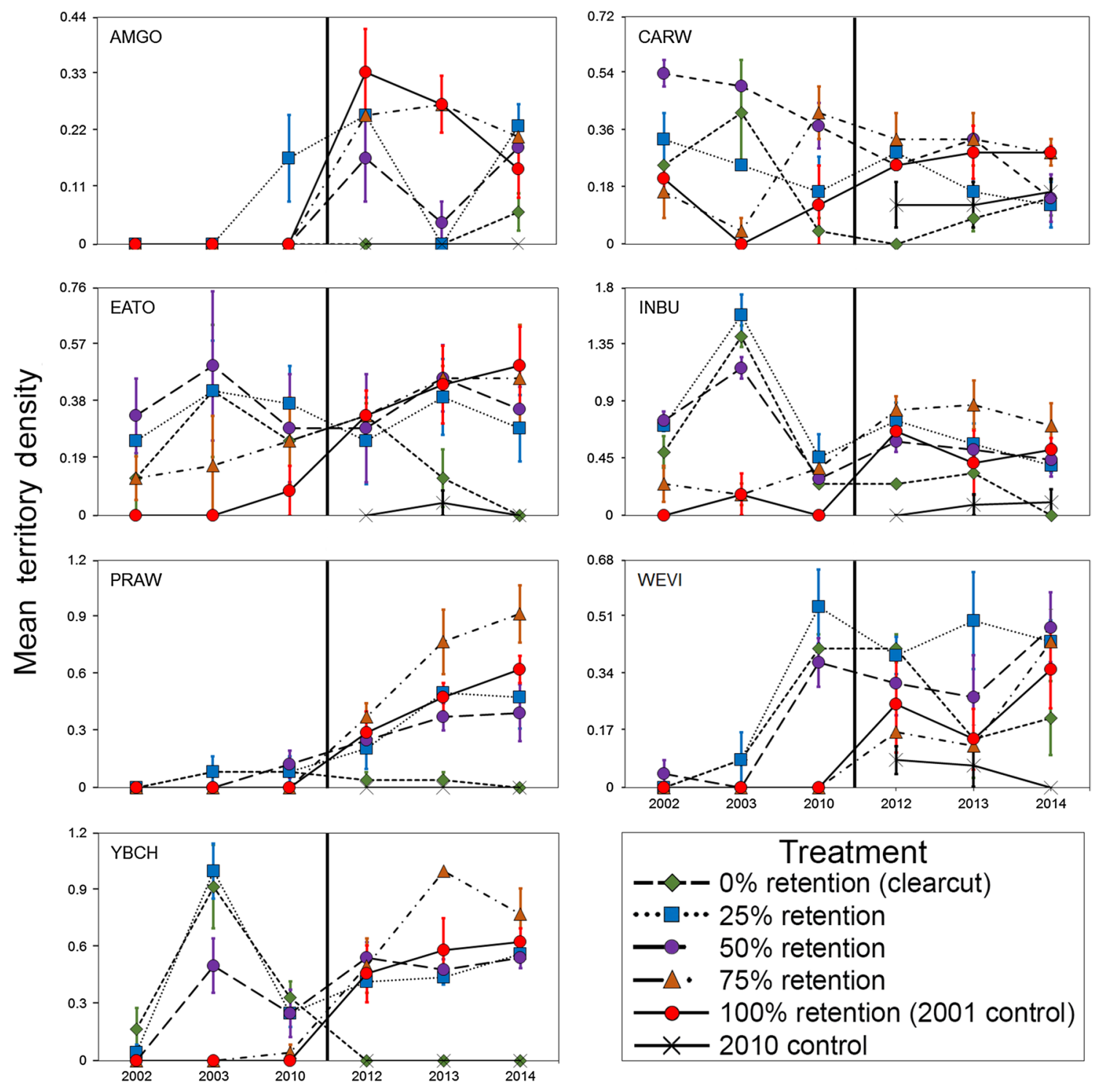

\section{Year sampled}

Fig. 4 Mean territory density (territories/ha) and standard error of seven early-successional species' (AMGO_American Goldfinch, CARW—Carolina Wren, EATO—Eastern Towhee, INBU—Indigo Bunting, PRAW—Prairie Warbler, WEVI—White-eyed Vireo, YBCH—Yellow-breasted Chat) to six different silviculture treatments ( $0 \%$ retention, $25 \%$ retention, 50\% retention, $75 \%$ retention, $100 \%$ retention, 2010 control) in an upland hardwood forest over 13 years. Solid black vertical line indicates when stage two harvest occurred (2010)

except for $25 \mathrm{SW}$ which showed 1 year of increased densities followed by 2 years of decreased densities. While Carolina Wren densities in treatments receiving no tree harvest during stage two (OSW and 2010C) had lower densities relative to other treatments, this difference was not as evident compared to other species (Prairie Warbler and Yellow-breasted Chat). Eastern Towhees had moderate to high densities in treatments receiving some forms of disturbance (tree harvest or herbicide treatment; 0SW,
25SW, 50SW, and 75SW) during stage one. Prior to stage two tree harvest, Eastern Towhee densities were similar in disturbed treatments, with the undisturbed treatment (100SW) also being occupied. Following stage two harvest, Eastern Towhee densities remained high with minor increases in treatments receiving tree harvest (25SW, $50 \mathrm{SW}, 75 \mathrm{SW}$, and $100 \mathrm{SW})$. Treatments that were left undisturbed during stage two (OSW and 2010C) had low 
Table 1 Observed territories of focal species for all sampling years

\begin{tabular}{|c|c|c|c|c|c|c|}
\hline Common name & 2002 & 2003 & 2010 & 2012 & 2013 & 2014 \\
\hline American Goldfinch & 0 & 0 & 2 & 12 & 7 & 10 \\
\hline Carolina Wren & 17 & 14 & 14 & 15 & 16 & 14 \\
\hline Eastern Towhee & 10 & 18 & 15 & 20 & 23 & 19 \\
\hline Indigo Bunting & 25 & 54 & 16 & 15 & 34 & 26 \\
\hline Prairie Warbler & 0 & 2 & 4 & 14 & 26 & 29 \\
\hline White-eyed Vireo & 0 & 2 & 16 & 20 & 16 & 23 \\
\hline Yellow-breasted Chat & 2 & 29 & 11 & 20 & 30 & 30 \\
\hline
\end{tabular}

15 stands were sampled in 2002, 2003, and 2010, while 18 stands were sampled in 2012, 2013, and 2014

densities relative to other treatments. Observed territories of focal species are presented in Table 1.

\section{Discussion}

Bird species' responses varied with respect to treatment and time after the tree harvest, indicating a dynamic response across time and management by bird species. Treatments that were expected to provide habitat for early-successional bird species (e.g., OSW) did so, but given enough time, plant succession transitioned to a stem-exclusion stage, ultimately reducing usage by our focal bird species. This example highlights the importance of early-successional bird species oriented management for the long-term persistence of the earlysuccessional group of birds in forested regions of the eastern US. Our study showed that early-successional birds can be managed over a longer period of time (13 years) using a two-stage shelterwood harvest.

Following stage one harvest, Carolina Wrens, Eastern Towhees, Indigo Buntings, and Yellow-breasted Chats were recorded in high densities during the second year, showing marked increases from year one (Fig. 4). The delayed response for American Goldfinch, Prairie Warblers, and White-eyed Vireos (i.e., no increase in territory density from 2002 to 2003) was likely due to a delayed vegetation response (possibly due to dormant season harvesting, Keyser and Zarnoch 2014) in the understory (Conner and Adkisson 1975; Schweitzer and Dey 2011). Reaching treatment-minimum canopy levels in 2003 for 0SW, 25SW, and 50SW stands (Fig. 2) likely induced growth of the understory vegetation layer, driving early-successional bird species' presence in these treatments. Immediately following stage one harvest, Carolina Wrens and Eastern Towhees likely used tangles and undergrowth thickets (Brawn et al. 2001), and the presence of slash piles left behind from logging provided nesting habitat following OSW tree harvest $(\mathrm{McD}$ ermott and Wood 2009). Indigo Bunting and Yellow-breasted Chat occupancy in OSW during stage one was likely in response to openings in the canopy (Strelke and Dickson
1980; Costello et al. 2000; Greenberg et al. 2014), creating dense layers of vegetation (e.g., Rubus spp., Ricketts and Ritchison 2000) for nesting cover. American Goldfinch's lack of immediate response to OSW was likely due to their preference for semi-open areas with standing trees (Middleton and McGraw 2009), which OSW stands did not provide. The delayed response of Prairie Warblers and White-eyed Vireos to OSW stands in stage one may be due to location of treatments as these relatively small cuts were isolated within a primarily forested area (Morris et al. 2013), may be due to demographics (see Akresh et al. 2015 for Prairie Warbler example), or delayed vegetation response which limited nesting availability.

Stage-two harvest rejuvenated understory habitat for focal birds, as Indigo Buntings and Yellow-breasted Chats responded immediately to stage-two harvest (similar to phase one) with increased densities in all but OSW and 2010C stands. Our sequential harvests (in 2002 and 2010) of 25SW and 50SW stands created freshly disturbed habitat for focal birds. Stage-two tree harvest in the $75 \mathrm{SW}$ and $100 \mathrm{SW}$ stands created even further disturbance for focal birds. Prairie Warblers' density continued to increase through 2012 and was the second most abundant bird species in 2014 (Table 1). American Goldfinch and Prairie Warblers intermediate response years (3-8 years post-harvest) were missed during phase one but showed positive responses to stage two harvest. Carolina Wrens, Eastern Towhees, and White-eyed Vireos all maintained abundant numbers during phase two. Increased focal bird density following stage two harvest was potentially due to increased structural complexity in these stands, as open canopy conditions facilitated herbaceous growth in the already semi-dense understory while fast-growing stump sprouts and non-merchantable residual midstory trees provided additional vertical structure.

Close proximity of stands may confound songbird usage or mislead songbird-treatment relationships (Hachè et al. 2013) as bird territories may encompass multiple stands. While stand sizes were not ideal, this study (along with others) demonstrates 
that small tree cuttings can support many individuals of the same species. Management for songbirds using smaller areas could become a popular practice in the future, due to private land ownership and parcelization throughout the eastern US (Fredericksen et al. 1999; Brooks 2003). Additionally, 4 ha is above thresholds for accommodating multiple territories of target species ( $\geq 0.6$ ha, Askins et al. 2007; $\geq 1.2$ ha, Chandler et al. 2009; $\geq 0.23$ ha, Roberts and King 2017). Also, territories of birds were estimated as individuals were not color-banded for re-sighting. To reconcile both of these limitations (close proximity of stands and lack of color-banded individuals), we used occurrence thresholds and divided territories into $1 / 2$ and $1 / 4$ depending on territory location. To identify unique individuals, individual territories were delineated only if observers recorded simultaneous songs between conspecifics. This reduced the possibility of double-recording or false-positives. Another limitation is that we did not survey the bird community during 2004-2009, but literature supports our expectations of temporal patterns exhibited by focal bird species in response to timber management in the eastern US (3-8 years post-harvest; Gram et al. 2003; Perry and Thill 2013; Akresh et al. 2015).

The comparison between both vegetation and bird responses in 2002 (following stage one) and 2011-12 (following stage two) should be noted. Stem counts in 2011 did not decrease to 2002 levels following tree harvest despite having all remaining canopies removed. While stage two harvest was 'prepared' prior to the final cut, stage one harvest had no site preparation; thus we would not expect to detect such immediate affects from tree cutting in stage one as in stage two. The presence of stump sprouts played an important role in maintaining early-successional birds in these treatments, as all bird species showed no major reduction in mean territory density in 2012. The second harvest extended species' presence beyond what similar studies have reported using a single harvest event approach. Early-successional vegetation is often short-lived, and management for birds is also shortlived reaching maximum bird abundances/densities 2-8 years post-harvest before populations begin to decline (Robinson and Robinson 1999; Keller et al. 2003; Twedt and Somershoe 2009). Over time bird densities return to pretreatment levels (Yahner 2003; Twedt and Somershoe 2009; Morris et al. 2013) once canopy gaps close and shade intolerant plants associated with disturbance die off. Our results reinforce what DeGraaf and Yamasaki (2003) and Twedt and Somershoe (2009) both recommended; that stands should be reevaluated 15 years after tree harvest to decide whether areas should be re-disturbed to recreate early-successional habitat conditions.

\section{Conclusion}

Compared with the clearcutting and other shelterwood methods of similar studies, the two-stage shelterwood method retained early-successional bird species longer. Though a shelterwood harvest is meant to regenerate trees, with the final harvest setting the stage for the next rotation, shelterwood cuts diminish in their capacity to provide early-successional habitat as stands eventually mature beyond the early-successional stage. Despite this, non-research entities are interested in the shelterwood method primarily to provide conditions conducive to regenerating oaks and hickories. Further use of the two-stage shelterwood method by land managers will likely benefit early-successional bird species. We suggest further investigation into the potential for two-stage shelterwood methods for the long-term management of early-successional or disturbancedependent breeding songbirds.

\section{Authors' contributions}

CJS designed the silviculture experiment. YW implemented the songbird component of the research. BKS and ELM collected the data. ELM finished the data analysis and wrote the first draft. CJS and YW supervised the research and provided multiple revisions in the early stages of writing. All authors read and approved the final manuscript.

\section{Author details \\ ${ }^{1}$ Department of Biological and Environmental Sciences, Alabama A\&M University, Normal, AL 35762, USA. ${ }^{2}$ West Virginia Cooperative Fish and Wildlife Research Unit, School of Natural Resources, West Virginia University, Mor- gantown, WV 26506, USA. ${ }^{3}$ Southern Research Station, United States Forest Service, Huntsville, AL 35801, USA.}

\section{Acknowledgements}

We thank AA Lesak for his previous work on this project, and AW Cantrell for his help throughout this project. We thank the Alabama Department of Conservation and Natural Resources and Stevenson Land Company for allowing us to work on their property, and the USDA Forest Service, Southern Research Station for allowing us to work at their research sites. We thank R Sisk and M Zerbil for their help during the field season, as well as the many technicians that helped on this project.

\section{Competing interests}

The authors declare they have no competing interests.

\section{Consent for publication}

Not applicable.

\section{Ethics approval and consent to participate}

The experiments comply with the current laws of the United States of America.

\section{Funding}

This research was funded by the Center for Forest Ecosystem Assessment (CFEA), USDA Forest Service, and Alabama A\&M University, with additional funding from the Alabama Ornithological Society and Birmingham Audubon Society.

Received: 1 December 2017 Accepted: 19 August 2018 Published online: 28 August 2018 


\section{References}

Akresh ME, King DI, Brooks RT. Demographic response of a shrubland bird to habitat creation, succession, and disturbance in a dynamic landscape. For Ecol Manag. 2015;336:72-80.

Annand EM, Thompson FR III. Forest bird response to regeneration practices in central hardwood forests. J Wildl Manag. 1997;61:159-71.

Askins RA. Sustaining biological diversity in early successional communities: the challenge of managing unpopular habitats. Wild I Soc B. 2001:29:407-12

Askins RA, Zuckerberg B, Novak L. Do the size and landscape context of fores openings influence the abundance and breeding success of shrubland songbirds in southern New England. Forest Ecol Manag. 2007;250:137-47.

Augenfeld KH, Franklin SB, Snyder DH. Breeding bird communities of upland hardwood forest 12 years after shelterwood logging. For Ecol Manag. 2008;255:1271-82.

Babyak MA. What you see may not be what you get: a brief, nontechnical introduction to overfitting in regression-type models. Psychosom Med. 2004;66:411-21.

Baker MD, Lacki MJ. Short-term changes in bird communities in response to silvicultural prescriptions. For Ecol Manag. 1997:96:27-36

Bibby CJ, Burgess ND, Hill DA, Mustoe SH. Bird census techniques. 2nd ed. San Diego: Academic Press; 2000.

Blake JG, Karr JR. Breeding birds of isolated woodlots: area and habitat relationship. Ecology. 1987;68:1724-34.

Brawn JD, Robinson SK, Thompson FR III. The role of disturbance in the ecology and conservation of birds. Annu Rev Ecol Syst. 2001;32:251-76.

Brooks RT. Abundance, distribution, trends, and ownership patterns of earlysuccessional forests in the northeastern United States. For Ecol Manag. 2003;185:65-74.

Campbell SP, Witham JW, Hunter ML Jr. Long-term effects of group-selection timber harvesting on abundance of forest birds. Conserv Biol. 2007;21:1218-29.

Chandler RB, King DI, Chandler CC. Effects of management regime on the abundance and nest survival of shrubland birds in wildlife openings in northern New England, USA. For Ecol Manag. 2009;258:1669-76.

Chandler CC, King DI, Chandler RB. Do mature forest birds prefer earlysuccessional habitat during the post-fledging period? For Ecol Manag. 2012;264:1-9.

Confer JL, Pascoe SM. Avian communities on utility rights-of-ways and other managed shrublands in the northeastern United States. For Ecol Manag. 2003;185:193-205.

Conner RN, Adkisson CS. Effects of clearcutting on the diversity of breeding birds. J For. 1975;73:781-5.

Costello CA, Yamasaki M, Pekins PJ, Leak WB, Neefus CD. Songbird response to group selection harvests and clearcuts in a New Hampshire northern hardwood forest. For Ecol Manag. 2000;127:41-54.

Decocq Q, Aubert M, Dupont F, Alard D, Saguez R, Wattez-Franger A, De Foucault B, Delelis-Dusollier A, Bardat J. Plant diversity in a managed temperate deciduous forest: understory response to two silvicultural systems. J Appl Ecol. 2004;41:1065-79.

DeGraaf RM, Yamasaki M. Options for managing early-successional forest and shrubland bird habitats in the northeastern United States. For Ecol Manag. 2003;185:179-91.

Dettmers R. Status and conservation of shrubland birds in the northeastern US. For Ecol Manag. 2003;185:81-93.

Drummond MA, Loveland TR. Land-use pressure and a transition to forestcover loss in the eastern United States. Bioscience. 2010;60:286-98.

Fiala ACS, Garman SL, Gray AN. Comparison of five canopy estimation techniques in the western Oregon Cascades. For Ecol Manag. 2006:232:188-97.

Franklin JF. Toward a new forestry. Am For. 1989;95:37-44.

Franklin JF, Spies T, Perry D, Harmon M, McKee A. Modifying douglas-fir management regimes for nontimber objectives. In: Proceedings of the symposium "Douglas-fir: stand management for the future", Seattle. 1986;55:373-9.

Fredericksen TS, Ross BD, Hoffman W, Morrison ML, Beyea J, Johnson BJ, Lester $M B$, Ross E. Short-term understory plant community responses to timberharvesting intensity on non-industrial private forestlands in Pennsylvania. For Ecol Manag. 1999;116:129-39.

Freemark K, Collins B. Landscape ecology of birds breeding in temperate forest fragments. In: Hagan III JM, Johnston DW, editors. Ecology and conservation of neotropical migrant landbirds. Washington: Smithsonian Institution Press; 1992. p. 443-54.

Goodale E, Lalbhai P, Goodale UM, Ashton PMS. The relationship between shelterwood cuts and crown thinnings and the abundance and distribution of birds in a southern New England forest. For Ecol Manag. 2009;258:314-22

Gram WK, Porneluzi PA, Clawson RL, Faaborg J, Richter SC (2003) Effects of experimental forest management on density and nesting success of bird species in Missouri Ozark forests. Conserv Biol 17(5):1324-1337

Greenberg CH, Franzreb KE, Keyser TL, Zarnoch SJ, Simon DM, Warburton GS. Short-term response of breeding birds to oak regeneration treatments in upland hardwood forest. Nat Area J. 2014;34:409-22.

Hachè S, Pètry T, Villard MA. Numerical response to breeding birds following experimental selection harvesting in northern hardwood forests. Avian Conserv Ecol. 2013;8:4

Hansen AJ, Spies TA, Swanson FJ, Ohmann JL. Conserving biodiversity in managed forests. Bioscience. 1991;41:382-92.

Hunter WC, Buehler DA, Canterbury RA, Confer JL, Hamel PB. Conservation of disturbance-dependent birds in eastern North America. Wildl Soc B. 2001:29:440-55.

Keller JK, Richmond ME, Smith CR. An explanation of patterns of breeding bird species richness and density following clearcutting in northeastern USA forests. For Ecol Manag. 2003;174:541-64.

Keyser TL, Zarnoch SJ. Stump sprout dynamics in response to reductions in stand density for nine upland hardwood species in the southern Appalachia Mountain. For Ecol Manag. 2014;319:29-35.

King DI, Schlossberg S. Synthesis of the conservation value of the earlysuccessional stage in forests in eastern North America. For Ecol Manag. 2014;324:186-95.

Klaus NA, Buehler DA, Saxton AM. Forest management alternatives and songbirds breeding habitat on the Cherokee National Forest, Tennessee. J Wildl Manag. 2005;69:222-34

Korhonen L, Korhonen KT, Rautiainen M, Stenberg P. Estimation for forest canopy cover: a comparison of field measurement techniques. Silva Fenn. 2006;40:577-88.

Litvaitis JA. Shrublands and early-successional forests: critical habitats dependent on disturbance in the northeastern United States. For Ecol Manag. 2003;185:1-4.

Loftis DL. A shelterwood method for regenerating red oak in the southern Appalachians. For Sci. 1990;36:917-29.

Lorimer CG. Historical and ecological roles of disturbance in eastern North American forests: 9000 years of change. Wildl Soc B. 2001;29:425-39.

McDermott ME, Wood PB. Short- and long-term implications of clearcut and two-age silviculture for conservation of breeding forest birds in the central Appalachians, USA. Biol Conserv. 2009;142:212-20.

McDermott ME, Wood PB. Influence of cover and food resource variation on post-breeding bird used of timber harvests with residual canopy trees. Wilson J Ornithol. 2010;122:545-55.

McLaren MA, Cadman MD. Can novice volunteers provide credible data for bird surveys requiring song identification? J Field Ornithol. 1999:70:481-90.

Middleton AL, McGraw KJ. American Goldfinch (Spinus tristis). In: Poole A, Gill F, editors. The Cornell Lab of Ornithology Bird of North American Online. 2009. https://doi.org/10.2173/bna.80. Accessed 5 Oct 2017.

Morris DL, Porneluzi PA, Haslerig J, Clawson RL, Faaborg J. Results of 20 years of experimental forest management of breeding birds in Ozark forests of Missouri, USA. For Ecol Manag. 2013;310:747-60.

Newell FL, Rodewald AD. Management for oak regeneration: short-term effects on the bird community and suitability of shelterwood harvests for canopy songbirds. J Wildl Manag. 2012;76:683-93.

Oswalt SJ, Franzreb KE, Buehler DA. Changes in early-successional hardwood forest area in four bird conservation regions across four decades. In: McWilliams W, Roesch FA, editors. Monitoring across borders: 2010 Joint Meeting of the Forest Inventory and Analysis (FIA) symposium and the southern mensurationists. Asheville, USA: General Technical Report SRS-157; 2012. p. 87-93.

Perry RW, Thill RE. Long-term responses of disturbance-associated birds after different timber harvests. For Ecol Manag. 2013;307:274-83.

Ralph CJ, Geupel GR, Pyle P, Martin TE, DeSante DF. Handbook of field methods for monitoring landbirds. General Technical Report PSW-GTR 144-www. 
U.S. Department of Agriculture, Forest Service, Pacific Southwest Research Station. 1993.

Rankin DT, Perlut NG. The effects of Forest Stand Improvement Practices on occupancy and abundance of breeding songbirds. For Ecol Manag. 2015;335:99-107.

Ricketts MS, Ritchison G. Nesting success of Yellow-breasted Chats: effects of nest site and territory vegetation structure. Wilson Bull. 2000;112:510-6.

Roberts HP, King DI. Area requirements and landscape-level factors influencing shrubland birds. J Wildl Manag. 2017;81:1298-307.

Robinson WD, Robinson SK. Effects of selective logging on forest bird populations in a fragmented landscape. Conserv Biol. 1999;13:58-66.

Sallabanks R, Arnett EB, Marzluff JM. An evaluation of research on the effects of timber harvest on bird populations. Wild Soc B. 2000;28:1144-55.

Sauer JR, LinkWA. Analysis of the North American Breeding Bird Survey using hierarchical models. Auk. 2011;128:87-98.

Schlossberg S, King DI. Postlogging succession and habitat usage of shrubland birds. J Wildl Manag. 2009;73:226-31.

Schlossberg S, King DI, Chandler RB, Mazzei BA. Regional synthesis of habitat relationships in shrubland birds. J Wild Manag. 2010;74:1513-22.

Schweitzer CJ. First-year response of an upland hardwood forest to five levels of overstory tree retention. In: Conner KF, editor. Proceedings of the 12th biennial southern silviculture research conference. Asheville, USA: General Technical Report SRS-71; 2004. p. 287-91.

Schweitzer CJ, Dey DC. Forest structure, composition, and tree diversity response to a gradient of regeneration harvests in the mid-Cumberland Plateau escarpment region, USA. For Ecol Manag. 2011;262:1729-41.

Schweitzer CJ, Dey DC. Midstory shelterwood to promote natural Quercus reproduction on the mid-Cumberland Plateau, Alabama: status 4 years after final harvest. In: Kabrick JM, Dey DC, Knapp BO, Larson DR, Shifley $\mathrm{SR}$, Steizer HE, editors. Proceedings of the 20th central hardwood forest conference. General Technical Report NRS-P-167. Columbia, MO: U.S. Department of Agriculture, Forest Service, Northern Research Station. 2017. p. 87-98.

Smalley GW. Classification and evaluation of forest sites on the mid-Cumberland Plateau. General Technical Report SO-38. U.S. Department of Agriculture, Forest Service, Southern Forest Experiment Station. 1982.
Smetzer JR, King DI, Schlossberg S. Management regime influences shrubland birds and habitat conditions in the northern Appalachians, USA. J Wildl Manag. 2014;78:314-24.

Strelke WK, Dickson JG. Effect of forest clear-cut edge on breeding birds in east Texas. J Wildl Manag. 1980:44:559-67.

Swanson ME, Franklin JF, Beschta RL, Crisafulli CM, DellaSala DA, Hutto RL, Lindenmayer DB, Swanson FJ. The forgotten stage of forest succession: early-successional ecosystems on forest sites. Front Ecol Environ. 2011:9:117-25.

Thompson FR III, Probst JR, Raphael MG. Silvicultural options for Neotropical migratory birds. In: Finch DM, Stangel PW, editors. Status and management of Neotropical migratory birds. General Technical Report RM-229. Fort Collins, CO: U.S. Department of Agriculture, Forest Service, Rocky Mountain Research Station. 1993. p. 353-62.

Thompson FR III, Probst JP, Raphael MG. Impacts of silviculture: overview and management recommendations. In: Martin TE, Finch DM, editors. Ecology and management of neotropical migratory birds: a synthesis and review of critical ideas. New York: Oxford University Press; 1995. p. 201-19.

Trani MK, Brooks RT, Schmidt TL, Rudis VA, Gabbard CM. Patterns and trends in early successional forests in the eastern United States. Wildl Soc B. 2001;29:413-24.

Twedt DJ, Somershoe SG. Bird response to prescribed silvicultural treatments in bottomland hardwood forests. J Wildl Manag. 2009;73:1140-50.

Vanderwel MC, Malcolm JR, Mills SC. A meta-analysis of bird responses to uniform partial harvesting across North America. Conserv Biol. 2007:21:1230-40

Vega Rivera JH, Rappole JH, McShea WJ, Haas CA. Wood thrush postfledging movements and habitat use in northern Virginia. Condor. 1998;100:69-78.

Vitz AC, Rodewald AD. Can regenerating clearcuts benefit mature-forest songbirds? An examination of post-breeding ecology. Biol Conserv. 2006:127:477-86.

Yahner RH. Responses of bird communities to early successional habitat in a managed landscape. Wilson Bull. 2003;115:292-8.
Ready to submit your research? Choose BMC and benefit from:

- fast, convenient online submission

- thorough peer review by experienced researchers in your field

- rapid publication on acceptance

- support for research data, including large and complex data types

- gold Open Access which fosters wider collaboration and increased citations

- maximum visibility for your research: over $100 \mathrm{M}$ website views per year

At $\mathrm{BMC}$, research is always in progress.

Learn more biomedcentral.com/submissions 